\title{
Effects of dietary oil sources and calcium : phosphorus levels on growth performance, gut morphology and apparent digestibility of broiler chickens
}

\author{
N.R. Abdulla ${ }^{1,5}$, T.C. Loh $^{1,2 \#}$, H. Akit ${ }^{1}$, A.Q. Sazili, ${ }^{1,3}$ \& H.L. Foo ${ }^{4}$ \\ ${ }^{1}$ Department of Animal Science, Faculty of Agriculture, Universiti Putra Malaysia, 43400 \\ UPM Serdang, Selangor, Malaysia \\ ${ }^{2}$ Institute of Tropical Agriculture, Universiti Putra Malaysia, 43400 Serdang, Selangor, Malaysia \\ ${ }^{3}$ Halal Products Research Institute, Universiti Putra Malaysia, 43400 UPM Serdang, Selangor, Malaysia \\ ${ }^{4}$ Department of Bioprocess Technology, Faculty of Biotechnology and Biomolecular Science, Universiti Putra Malaysia, \\ 43400 UPM Serdang, Selangor, Malaysia. \\ ${ }^{5}$ Department of Animal Resource, University of Salah al- Din, Erbil, Iraq
}

(Received 21 June 2015; Accepted 16 December 2015; First published online 20 February 2016)

Copyright resides with the authors in terms of the Creative Commons Attribution 2.5 South African Licence.
See: http://creativecommons.org/licenses/by/2.5/za
Condition of use: The user may copy, distribute, transmit and adapt the work, but must recognise the authors and the South African
Journal of Animal Science.

\begin{abstract}
The study investigated the effects of varying dietary calcium ( $\mathrm{Ca}$ ) levels and sources of oil on performance of broiler chickens. A total of 378 one-day-old birds were fed $6 \%$ palm oil (PO), soybean oil (SO) or linseed oil (LO) in combination with three levels of $\mathrm{Ca}, 1 \%, 1.25 \%$ and $1.5 \%$, for six weeks in a $3 \times 3$ factorial experiment. Birds fed diet supplemented with SO and PO had higher average daily gains, more abdominal fat and greater villi height compared with those fed LO. However, feed efficiency, apparent digestibility of organic matter, ether extract, crude protein and ash were similar across treatments. Regardless of oil source, the chickens fed diets containing 1.5\% Ca had a lower bodyweight and apparent digestibility of organic matter, crude protein, ether extract and phosphorus $(P)$ than those fed $1 \%$ and $1.25 \%$ $\mathrm{Ca}$. In contrast, the birds fed $1.25 \% \mathrm{Ca}$ had higher ash, $\mathrm{Ca}$ and $\mathrm{P}$ digestibility than did the $1 \% \mathrm{Ca}$ birds. Interaction between source of oil and $\mathrm{Ca}$ level on mineral digestibility was significant. It can be concluded that palm oil could be used as an alternative to soybean and linseed oils to improve growth performance in broiler chickens. Moreover, increasing the level of $\mathrm{Ca}$ to $1.25 \%$ can improve broiler performance and apparent nutrient digestibility, regardless of the type of oil used in the current study.
\end{abstract}

Keywords: Broiler performance, dietary calcium levels, linseed oil, nutrient digestibility, palm oil, soybean oil, villus height

\#Corresponding author: tcloh@upm.edu.my

\section{Introduction}

Dietary fat plays an important role in poultry nutrition. Fat contains at least twice the available energy of carbohydrates and protein. Hence fat is widely used in broiler diets to meet the energy requirements of fast growing modern strains (Baião \& Lara, 2005). In addition, dietary fats enhance the absorption and utilization of fat-soluble vitamins, increase the palatability of rations, reduce pulverulence, improve the efficiency of the energy consumed (Baião \& Lara, 2005; Zulkifli et al., 2007; Chwen et al., 2013) and reduce the rate of passage of digesta in the gastrointestinal tract, which gives room for adequate and efficient absorption of the nutrients present in such diets (Baião \& Lara, 2005). Moreover, the fatty acid profile of muscle tissue reflected the dietary fatty acid profile (Maroufyan et al., 2013; Abdulla et al., 2015). On the other hand, when fats are digested, free fatty acids may produce a complex with calcium $(\mathrm{Ca})$ and form insoluble or soluble soaps (Atteh \& Leeson, 1983). Formation of soluble soap may render the fatty acids and Ca unavailable for absorption (Leeson \& Atteh, 1995; Leeson \& Summer, 2005). Atteh \& Leeson (1983) reported that a large percentage of saturated fatty acids in chicken excreta was present as unutilized soap in contrast with that observed with unsaturated fatty acids. This can jeopardize the energy value of the fat and interfers with the bird's mineral retention, and bone and eggshell quality. Thus, addition of fat to poultry diet necessitates the addition of $\mathrm{Ca}$ for better poultry performance. The benefits of $\mathrm{Ca}$ supplementation on the production performance of poultry have been underscored (Underwood \& Suttle, 2001; Peters \& Mahan, 2008). Calcium has important biological functions and must be provided in adequate amounts. Inadequate $\mathrm{Ca}$ intake may affect bone mineral content, muscle function and other body mineral functions (Peters \& 
Mahan, 2008). The modern broiler has been intensively selected for higher growth rates and increased feed conversion. Today, broilers are ready for market at 6 weeks old with a bodyweight of $2.6 \mathrm{~kg}$ (Santos et al., 2005). Unfortunately, the mineral requirements of broiler chickens, as determined by several organizations 10 to 20 years ago, may not support optimal chicken performance in today's strains (Ruttanavut \& Yamauchi, 2010). Intestinal mucosa plays an important role as the site of nutrient absorption in the small intestine (Julendra et al., 2012). The histology of the epithelial cells on the villus apical surface and intestinal villi is influenced by dietary feed components (McDonald et al., 2002). Thus, increasing mineral levels and different dietary oil may affect intestinal function. Although some investigations have been conducted on the influence of dietary oil sources and $\mathrm{Ca}$ requirement on broiler performance and apparent digestibility (Kavouridou et al., 2008; Jankowski et al., 2012), information on the interaction of dietary oil sources and different levels of $\mathrm{Ca}$ is limited. Therefore, the objective of this study was to determine the effects of palm oil, soybean oil and linseed oil with three levels of $\mathrm{Ca}$ on growth performance, gut morphology and apparent digestibility in broiler chickens.

\section{Materials and Methods}

This study was conducted in line with the animal ethics guidelines of the Research Policy of the University of Putra, Malaysia.

A total of 378 male (Cobb 500) broilers obtained from a local hatchery were raised from day 1 to 42 days old in battery cages. After arrival, the chicks were wing-banded, weighed and randomly assigned to nine treatment groups. Each treatment consisted of six replicates (cages) and each replicate was made up of seven chicks. After seven days of the rearing period, all birds were vaccinated against Newcastle disease (ND) and infectious bronchitis (IB) with live vaccine (MyVac, Kuala Lumpur, Malaysia) through the intraocular route. The infectious bursal disease vaccine (IBD) (MyVac, Kuala Lumpur, Malaysia) was administered on day 14 through the same route. Birds had ad libitum access to feed and water. The housing conditions and lighting programme were in line with commercial recommendations. Ambient temperature in the first seven days was $35^{\circ} \mathrm{C}$ and decreased to $28^{\circ} \mathrm{C}$ until the end of experiment. Twenty two hours of light were provided in the first seven days, and was reduced to $20 \mathrm{~h}$ afterwards. The starter and finisher diets were offered to the birds from 0 to 21 and 22 to 42 days old, respectively. The diets contained three types of oil, namely linseed oil (LO), soybean oil (SO) and palm oil (PO), and three levels of Ca: P viz. $1: 0.5,1.25: 0.63$ and $1.5: 0.75$ (NRC, 1994). Diets were formulated to meet the requirements of all nutrients for broiler chickens using FeedLIVE software (FeedLIVE 1.52, Thailand). Tables 1 and 2 show the percentage compositions of the starter and finisher diets, respectively.

Pen feed intake and individual bodyweight were recorded weekly. The average daily gain and feed conversion ratio (FCR) were calculated. Six broiler chicks at day 21 and 12 at day 42 were randomly selected from each treatment and slaughtered for sampling. The slaughter process was conducted at the Department of Animal Science Research Abattoir, Faculty of Agriculture, University of Putra, Malaysia. The animals were slaughtered according to the Halal slaughter procedure as outlined in the Standards Malaysia 1500 (Department of Standards Malaysia 2009). The Halal slaughter was performed by a licensed slaughter man. The head of each bird was pulled dorsally to stretch the neck in order to facilitate exsanguination. A transverse section was performed with a sharp knife. The neck cut severes muscle, esophagus, trachea, carotid arteries, jugular, venis and major nerves without decapitating the bird in the process. The sectioning and weighing of internal organs and abdominal fat were conducted as described by Sola-Ojo et al. (2013). Small intestine and ileal content were sampled for further analysis.

Intestinal morphology was conducted in line with the method described by Choe et al. (2012). About $5-6 \mathrm{~cm}$ long segments of ileum (midway between the Meckel's diverticulum and the ileo-cecal junction), jejunum (midway between the end point of duodenal loop and Meckel's diverticulum) and duodenum (the middle part of the duodenal loop) were collected. A $10 \%$ neutral buffered formalin solution was used to flush the intestinal samples. Thereafter, the segments were fixed in $10 \%$ neutral buffered formalin solution overnight. The intestinal samples were excised, dehydrated in a tissue processing machine (Leica Microsystems K.K., Tokyo, Japan) and embedded in paraffin wax. Sections of $4 \mathrm{~mm}$ were cut from each sample, fixed on slides, stained with haematoxylin and eosin, mounted and examined under light microscopes. The crypt depth (the depth of the invagination between adjacent villi) and villi height (from the tip of the villi to the villi crypt junction) were measured with an image analyser. Twelve vertically oriented villi and crypts from each slide were measured.

During the last three days of the starter and finisher stages (18 to $21 \mathrm{~d}$ and 39 to $42 \mathrm{~d}$ ), an indigestible marker, titanium dioxide $\left(\mathrm{TiO}_{2}\right)$ at an inclusion level of $3 \mathrm{~g} / \mathrm{kg}$, was added to the diet for each cage. After slaughter, the ileal content was taken and stored at $-20^{\circ} \mathrm{C}$ until laboratory analyses were conducted. The ileal content sample was dried to a constant weight at $80^{\circ} \mathrm{C}$, and homogenized. The $\left(\mathrm{TiO}_{2}\right)$ contents of feed 
Table 1 Composition of the starter diet $(\mathrm{g} / \mathrm{kg})$ and calculated nutrient content

\begin{tabular}{|c|c|c|c|c|c|c|c|c|c|}
\hline \multirow{2}{*}{ Ingredients } & \multicolumn{3}{|c|}{$\mathrm{PO}^{1}$} & \multicolumn{3}{|c|}{ so $^{1}$} & \multicolumn{3}{|c|}{ LO $^{1}$} \\
\hline & $\mathrm{Ca}^{2} 1$ & $\mathrm{Ca} 2$ & Ca3 & Ca1 & $\mathrm{Ca} 2$ & Ca3 & Ca1 & $\mathrm{Ca} 2$ & Ca3 \\
\hline Maize & 399.5 & 412.8 & 426.5 & 399.5 & 412.8 & 426.5 & 399.5 & 412.8 & 426.5 \\
\hline Soybean meal & 400.0 & 406.0 & 412.5 & 400.0 & 406.0 & 412.5 & 400.0 & 406.0 & 412.5 \\
\hline Palm oil & 60.0 & 60.0 & 60.0 & 0 & 0 & 0 & 0 & 0 & 0 \\
\hline Soybean oil & 0 & 0 & 0 & 60.0 & 60.0 & 60.0 & 0 & 0 & 0 \\
\hline Linseed oil & 0 & 0 & 0 & 0 & 0 & 0 & 60.0 & 60.0 & 60.0 \\
\hline Wheat pollard & 97.7 & 68.8 & 38.9 & 97.7 & 68.8 & 38.9 & 97.7 & 68.8 & 38.9 \\
\hline $\mathrm{MDCP}^{3} 21 \%$ & 15.9 & 22.8 & 29.8 & 15.9 & 22.8 & 29.8 & 15.9 & 22.8 & 29.8 \\
\hline Calcium carbonate & 14.7 & 17.5 & 20.2 & 14.7 & 17.5 & 20.2 & 14.7 & 17.5 & 20.2 \\
\hline Salt & 3.0 & 3.0 & 3.0 & 3.0 & 3.0 & 3.0 & 3.0 & 3.0 & 3.0 \\
\hline L-Lysine & 2.5 & 2.5 & 2.5 & 2.5 & 2.5 & 2.5 & 2.5 & 2.5 & 2.5 \\
\hline DL-Methionine & 2.0 & 2.0 & 2.0 & 2.0 & 2.0 & 2.0 & 2.0 & 2.0 & 2.0 \\
\hline Antioxidant $^{4}$ & 0.2 & 0.2 & 0.2 & 0.2 & 0.2 & 0.2 & 0.2 & 0.2 & 0.2 \\
\hline Vitamin premix ${ }^{5}$ & 1.0 & 1.0 & 1.0 & 1.0 & 1.0 & 1.0 & 1.0 & 1.0 & 1.0 \\
\hline Mineral premix ${ }^{6}$ & 1.5 & 1.5 & 1.5 & 1.5 & 1.5 & 1.5 & 1.5 & 1.5 & 1.5 \\
\hline Choline chloride & 1.0 & 1.0 & 1.0 & 1.0 & 1.0 & 1.0 & 1.0 & 1.0 & 1.0 \\
\hline Toxin binder $^{7}$ & 1.0 & 1.0 & 1.0 & 1.0 & 1.0 & 1.0 & 1.0 & 1.0 & 1.0 \\
\hline \multicolumn{10}{|c|}{ Calculated nutrient content $(\mathrm{g} / \mathrm{kg})^{8}$} \\
\hline $\mathrm{ME}(\mathrm{MJ} / \mathrm{kg})$ & 13.0 & 13.0 & 13.0 & 13.0 & 13.0 & 13.0 & 13.0 & 13.0 & 13.0 \\
\hline Crude protein & 220.2 & 220.1 & 220.1 & 220.2 & 220.1 & 220.1 & 220.2 & 220.1 & 220.1 \\
\hline $\mathrm{ME} / \mathrm{CP}^{9}$ & 0.59 & 0.59 & 0.59 & 0.59 & 0.59 & 0.59 & 0.59 & 0.59 & 0.59 \\
\hline Crude fat & 77.8 & 78.3 & 78.9 & 77.8 & 78.3 & 78.9 & 77.8 & 78.3 & 78.9 \\
\hline Fibre & 45.5 & 44.0 & 42.5 & 45.5 & 44.0 & 42.5 & 45.5 & 44.0 & 42.5 \\
\hline Calcium & 10.0 & 12.5 & 15.0 & 10.0 & 12.5 & 15.0 & 10.0 & 12.5 & 15.0 \\
\hline Total phosphorus & 8.3 & 9.6 & 11.0 & 8.3 & 9.6 & 11.0 & 8.3 & 9.6 & 11.0 \\
\hline Avail. P for poultry & 4.5 & 5.6 & 6.8 & 4.5 & 5.6 & 6.8 & 4.5 & 5.6 & 6.8 \\
\hline Arginine & 15.7 & 15.8 & 15.8 & 15.7 & 15.8 & 15.8 & 15.7 & 15.8 & 15.8 \\
\hline Lysine & 12.8 & 12.9 & 13.0 & 12.8 & 12.9 & 13.0 & 12.8 & 12.9 & 13.0 \\
\hline Methionine+cystine & 8.9 & 9.0 & 9.0 & 8.9 & 9.0 & 9.0 & 8.9 & 9.0 & 9.0 \\
\hline Methionine & 5.4 & 5.4 & 5.5 & 5.4 & 5.4 & 5.5 & 5.4 & 5.4 & 5.5 \\
\hline Threonine & 8.6 & 8.7 & 8.7 & 8.6 & 8.7 & 8.7 & 8.6 & 8.7 & 8.7 \\
\hline Tryptophan & 3.0 & 3.0 & 3.0 & 3.0 & 3.0 & 3.0 & 3.0 & 3.0 & 3.0 \\
\hline
\end{tabular}

${ }^{1} \mathrm{PO}: 6 \%$ of palm oil in diet; SO: $6 \%$ of soybean oil in diet; LO: $6 \%$ of linseed oil in diet.

${ }^{2} \mathrm{Ca1}$ : $1 \%$ calcium and $0.45 \%$ available phosphorus, Ca2: $1.25 \%$ calcium and $0.56 \%$ available phosphorus; Ca3: $1.50 \%$ calcium and $0.67 \%$ available phosphorus.

${ }^{3}$ Mono dicalcium phosphate.

${ }_{5}^{4}$ Antioxidant contains butylated hydroxyanisole (BHA).

${ }^{5}$ Supplied per kg diet: Vitamin A $11494 \mathrm{IU}$; vitamin D $1725 \mathrm{IU}$; vitamin E $40 \mathrm{IU}$; vitamin $\mathrm{K}_{3} 2.29 \mathrm{mg}$; cobalamin $0.05 \mathrm{mg}$; thiamine $1.43 \mathrm{mg}$; riboflavin $3.44 \mathrm{mg}$; folic acid $0.56 \mathrm{mg}$; biotin $0.05 \mathrm{mg}$; panthothenic acid $6.46 \mathrm{mg}$; niacin $40.17 \mathrm{mg}$; pyridoxine $2.29 \mathrm{mg}$.

${ }^{6}$ Supplied per kg diet: Fe 120 mg; Mn 150 mg; Cu 15 mg; Zn 120 mg; I 1.5 mg; Se 0.3 mg; Co 0.4 mg

${ }^{7}$ Toxin binder contains natural hydrated sodium calcium aluminium silicates (HSCAS).

${ }^{8}$ The diets were formulated using feed live International software (Thailand).

${ }^{9} \mathrm{ME} / \mathrm{CP}$ : metabolizable energy (MJ/ kg) to protein (\%) ratio. 
Table 2 Composition of the finisher diet $(\mathrm{g} / \mathrm{kg})$ and calculated nutrient content

\begin{tabular}{|c|c|c|c|c|c|c|c|c|c|}
\hline \multirow{2}{*}{ Ingredients } & \multicolumn{3}{|c|}{$\mathrm{PO}^{1}$} & \multicolumn{3}{|c|}{$\mathrm{so}^{1}$} & \multicolumn{3}{|c|}{ LO $^{1}$} \\
\hline & ${ }^{2} \mathrm{Ca} 1$ & Ca 2 & $\mathrm{Ca3}$ & Ca1 & Ca 2 & $\mathrm{Ca} 3$ & Ca1 & Ca 2 & $\mathrm{Ca} 3$ \\
\hline Maize & 483.5 & 495.0 & 507.0 & 483.5 & 495.0 & 507.0 & 483.5 & 495.0 & 507.0 \\
\hline Soybean meal & 328.7 & 334.4 & 339.6 & 328.7 & 334.4 & 339.6 & 328.7 & 334.4 & 339.6 \\
\hline Palm oil & 60.0 & 60.0 & 60.0 & 0 & 0 & 0 & 0 & 0 & 0 \\
\hline Soybean oil & 0 & 0 & 0 & 60.0 & 60.0 & 60.0 & 0 & 0 & 0 \\
\hline Linseed oil & 0 & 0 & 0 & 0 & 0 & 0 & 60.0 & 60.0 & 60.0 \\
\hline Wheat pollard & 89.0 & 63.5 & 38.0 & 89.0 & 63.5 & 38.0 & 89.0 & 63.5 & 38.0 \\
\hline $\mathrm{MDCP}^{3} 21 \%$ & 10.7 & 16.1 & 21.6 & 10.7 & 16.1 & 21.6 & 10.7 & 16.1 & 21.6 \\
\hline Calcium carbonate & 15.4 & 18.3 & 21.2 & 15.4 & 18.3 & 21.2 & 15.4 & 18.3 & 21.2 \\
\hline Salt & 3.0 & 3.0 & 3.0 & 3.0 & 3.0 & 3.0 & 3.0 & 3.0 & 3.0 \\
\hline L-Lysine & 2.5 & 2.5 & 2.5 & 2.5 & 2.5 & 2.5 & 2.5 & 2.5 & 2.5 \\
\hline DL-Methionine & 2.0 & 2.0 & 2.0 & 2.0 & 2.0 & 2.0 & 2.0 & 2.0 & 2.0 \\
\hline Anti-oxidant ${ }^{4}$ & 0.2 & 0.2 & 0.2 & 0.2 & 0.2 & 0.2 & 0.2 & 0.2 & 0.2 \\
\hline Vitamin premix ${ }^{5}$ & 1.0 & 1.0 & 1.0 & 1.0 & 1.0 & 1.0 & 1.0 & 1.0 & 1.0 \\
\hline Mineral premix ${ }^{6}$ & 1.5 & 1.5 & 1.5 & 1.5 & 1.5 & 1.5 & 1.5 & 1.5 & 1.5 \\
\hline Choline chloride & 1.0 & 1.0 & 1.0 & 1.0 & 1.0 & 1.0 & 1.0 & 1.0 & 1.0 \\
\hline Toxin binder $^{7}$ & 1.5 & 1.5 & 1.5 & 1.5 & 1.5 & 1.5 & 1.5 & 1.5 & 1.5 \\
\hline \multicolumn{10}{|c|}{ Calculated nutrient content $(\mathrm{g} / \mathrm{kg})^{8}$} \\
\hline ME (MJ/kg) & 13.3 & 13.3 & 13.3 & 13.3 & 13.3 & 13.3 & 13.3 & 13.3 & 13.3 \\
\hline Crude protein & 195.1 & 195.2 & 195.0 & 195.1 & 195.2 & 195.0 & 195.1 & 195.2 & 195.0 \\
\hline $\mathrm{ME} / \mathrm{CP}^{9}$ & 0.68 & 0.68 & 0.68 & 0.68 & 0.68 & 0.68 & 0.68 & 0.68 & 0.68 \\
\hline Crude fat & 80.1 & 80.6 & 81.1 & 80.1 & 80.6 & 81.1 & 80.1 & 80.6 & 81.1 \\
\hline Fibre & 42.0 & 40.7 & 39.4 & 42.0 & 40.7 & 39.4 & 42.0 & 40.7 & 39.4 \\
\hline Calcium & 9.0 & 11.3 & 13.5 & 9.0 & 11.3 & 13.5 & 9.0 & 11.3 & 13.5 \\
\hline Total phosphorus & 6.9 & 7.9 & 9.0 & 6.9 & 7.9 & 9.0 & 6.9 & 7.9 & 9.0 \\
\hline Avail. $\mathrm{P}$ for poultry & 3.5 & 4.4 & 5.3 & 3.5 & 4.4 & 5.3 & 3.5 & 4.4 & 5.3 \\
\hline Arginine & 13.5 & 13.6 & 13.7 & 13.5 & 13.6 & 13.7 & 13.5 & 13.6 & 13.7 \\
\hline Lysine & 10.9 & 11.0 & 11.1 & 10.9 & 11.0 & 11.1 & 10.9 & 11.0 & 11.1 \\
\hline Methionine+cystine & 8.2 & 8.3 & 8.3 & 8.2 & 8.3 & 8.3 & 8.2 & 8.3 & 8.3 \\
\hline Methionine & 5.1 & 5.1 & 5.1 & 5.1 & 5.1 & 5.1 & 5.1 & 5.1 & 5.1 \\
\hline Threonine & 7.6 & 7.6 & 7.7 & 7.6 & 7.6 & 7.7 & 7.6 & 7.6 & 7.7 \\
\hline Tryptophan & 2.6 & 2.6 & 2.6 & 2.6 & 2.6 & 2.6 & 2.6 & 2.6 & 2.6 \\
\hline
\end{tabular}

${ }^{1} \mathrm{PO}: 6 \%$ of palm oil in diet; SO: $6 \%$ of soybean oil in diet; LO: $6 \%$ of linseed oil in diet.

${ }^{2} \mathrm{Ca1}$ : $0.90 \%$ calcium and $0.35 \%$ available phosphorus; Ca2: $1.3 \%$ calcium and $0.44 \%$ available phosphorus; Ca3: $1.35 \%$ calcium and $0.90 \%$ available phosphorus.

${ }^{3}$ Mono dicalcium phosphate.

${ }_{5}^{4}$ Antioxidant contains butylated hydroxyanisole (BHA).

${ }^{5}$ Supplied per kg diet: Vitamin A $11494 \mathrm{IU}$; vitamin D $1725 \mathrm{IU}$; vitamin E $40 \mathrm{IU}$; vitamin $\mathrm{K}_{3} 2.29 \mathrm{mg}$; cobalamin $0.05 \mathrm{mg}$; thiamine $1.43 \mathrm{mg}$; riboflavin $3.44 \mathrm{mg}$; folic acid $0.56 \mathrm{mg}$; biotin $0.05 \mathrm{mg}$; pantothenic acid $6.46 \mathrm{mg}$; niacin $40.17 \mathrm{mg}$; pyridoxine $2.29 \mathrm{mg}$.

${ }^{6}$ Supplied per kg diet: Fe 120 mg; Mn 150 mg; Cu 15 mg; Zn 120 mg; I 1.5 mg; Se 0.3 mg; Co 0.4 mg.

7 Toxin binder contains natural hydrated sodium calcium aluminium silicates (HSCAS).

${ }^{8}$ The diets were formulated using FeedLIVE International software (Thailand).

${ }^{9} \mathrm{ME} / \mathrm{CP}$ : metabolizable energy (MJ/ kg) to protein (\%) ratio. 
and digesta were determined using a spectrophotometer after the samples had been ashed, dissolved in sulphuric acid (7.4 M) and reacted with hydrogen peroxide (Short et al., 1996), whereas the proximate analysis of nutrients was used to calculate nutrient digestibility of the feed and digesta (AOAC, 1995). The total $\mathrm{P}$ content of the digesta and feed were determined with an auto analyser (Lachat Instruments QuikChem 8000 Series FIA+ System) and the Ca was measured by atomic absorption spectrometry (Perkin Elmer Analyst 400). Apparent ileal digestibility (AID) of dry matter, CP, ether extract, Ca and P were calculated using titanium marker ratios in the diet and ileal content (Tancharoenrat \& Ravindran, 2014):

AID of nutrient $=\left[\left(\right.\right.$ nutrient $\left./ \mathrm{T}_{\mathrm{i}}\right) \mathrm{d}-\left(\right.$ nutrient $\left.\left./ \mathrm{T}_{\mathrm{i}}\right) \mathrm{j}\right] /\left(\right.$ nutrient $\left./ \mathrm{T}_{\mathrm{i}}\right) \mathrm{d} \times 100$

where (nutrient $\left./ \mathrm{T}_{\mathrm{i}}\right) \mathrm{d}=$ ratio of nutrient to titanium in the diet, and (nutrient $/ \mathrm{T}_{\mathrm{i}}$ ) $\mathrm{i}=$ ratio of nutrient to titanium in the ileal content.

The experiment followed a 3 (sources of oil) by 3 (levels of $\mathrm{Ca}$ and P) factorial arrangement in a completely randomized design. The data obtained were analysed using the generalized linear model of SAS (SAS, 2007). Significant differences between treatment means were compared using Duncan's multiple range test.

\section{Results and Discussion}

The bodyweight and feed intake of birds fed different oil sources, $\mathrm{Ca}$ and $\mathrm{P}$ levels are shown in Table 3. No significant differences $(P>0.05)$ in daily feed intake and FCR were observed among the various dietary oils. However, SO and PO increased average daily gain compared with linseed oil $(P<0.05)$. The lower average daily gain observed in birds fed LO could be due to the shorter duodenum and jejunum villi (Table 5) and reduced intestinal absorptive area. The lower average daily gain in LO birds corroborates the findings of Zhong et al. (2014) who observed that daily weight gain and final bodyweight were lower in broilers fed linseed oil in contrast to those fed palm oil. However, the present results contradict the findings of Fébel et al. (2008), who reported no significant difference in growth performance of the broilers fed diets supplemented with these oil sources, linseed oil, soybean oil and sunflower oil. De Witt et al. (2009) also reported that different dietary fatty acids had no effect on body weight gain.

Regardless of the oil source, there were no significant differences $(P>0.05)$ among the Ca levels for daily feed intake and FCR, but the average daily gain was significantly different $(P<0.05)$. Birds fed diets containing $1.5 \% \mathrm{Ca}$ requirements had lower $(P<0.05)$ bodyweight gains. Similar findings were reported by Smith et al. (2003), who observed no significant differences in feed intake and FCR of broilers fed different levels of dietary $\mathrm{Ca}$ and $\mathrm{P}$. Lower digestibility of organic matter, crude protein, ether extract, ash and $\mathrm{P}$ in birds fed high Ca diets (1.5\%) was obtained. This could be used to explain the negative effects of high Ca on bodyweight gain. These results are in agreement with those of Tancharoenrat \& Ravindran (2014), who investigated the influence of different dietary concentrations of $\mathrm{Ca}$ on the performance and ileal digestibility of fat, nitrogen, $\mathrm{Ca}$ and $\mathrm{P}$ in young broiler chickens and found that the higher concentration of dietary $\mathrm{Ca}$ reduced performance and the utilization of $\mathrm{P}, \mathrm{Ca}$, nitrogen and energy in broiler starters.

The interactions among different sources of oil and Ca levels were not significantly different $(P>0.05)$ for the growth performance of broiler chickens. The effects of dietary oil and Ca level on percentage abdominal fat and visceral organs in broiler chickens at 42 days old are shown in Table 4 . There were no significant differences $(P>0.05)$ among oil sources on weight of liver, gizzard and heart. Birds fed PO presented higher abdominal fat than those fed SO and LO. Abdominal fat is representative of the total fat deposition of the broiler chicken (Crespo \& Esteve-Garcia, 2002b). As in the current trial, other studies found a reduction in abdominal fat deposition in the broilers fed unsaturated fats (sunflower and linseed oil) compared with the birds fed saturated fat (olive oil) (Crespo \& Esteve-Garcia, 2001; Villaverde et al., 2005). In addition, Crespo \& Esteve-Garcia (2002a) reported lower abdominal fat deposition in birds fed linseed and sunflower oils compared with those fed olive oil. These findings were attributed to higher de novo fatty acid synthesis, which serves as a major means of energy dissipation and contributes to lower fat deposition found in the birds. Moreover, Kavouridou et al. (2008) showed that the animals fed linseed oil had a lower body fat content compared with those consuming coconut, palm, olive and soybean oil.

Irrespective of the oil sources, there was no significant difference $(P>0.05)$ among the Ca levels for abdominal fat and internal organ. This result is in agreement with that of Shafey (1999), who reported that Ca level did not influence visceral organ weight.

The interactions among different sources of oil and Ca levels were not significantly different $(P>0.05)$ for abdominal fat and internal organs. 
Table 3 Effect of dietary oil sources, calcium and phosphorus levels on growth performance of broiler chickens

\begin{tabular}{|c|c|c|c|c|c|c|c|c|c|c|}
\hline \multirow{2}{*}{ Parameter } & \multicolumn{3}{|c|}{ Oil source ${ }^{1}$} & \multicolumn{3}{|c|}{ Calcium level $^{2}$} & \multirow{2}{*}{ SEM } & \multicolumn{3}{|c|}{$P$-value } \\
\hline & PO & so & LO & Ca1 & $\mathrm{Ca2}$ & $\mathrm{Ca3}$ & & Oil & $\mathbf{C a}$ & Oil $\times \mathrm{Ca}$ \\
\hline \multicolumn{11}{|c|}{ Average daily gain $(\mathrm{g} / \mathrm{d})$} \\
\hline Week 1-3 & $28.55^{a}$ & $27.12^{b}$ & $27.11^{b}$ & $28.69^{a}$ & $28.50^{\mathrm{a}}$ & $25.59^{b}$ & 0.29 & 0.047 & 0.001 & 0.053 \\
\hline Week 4-6 & $77.53^{b}$ & $79.45^{\mathrm{a}}$ & $75.95^{b}$ & 77.84 & 78.40 & 76.68 & 0.36 & 0.003 & 0.127 & 0.310 \\
\hline Overall & $53.59^{\mathrm{a}}$ & $54.05^{\mathrm{a}}$ & $51.72^{b}$ & $53.96^{\mathrm{a}}$ & $53.86^{\mathrm{a}}$ & $51.55^{b}$ & 0.21 & 0.001 & 0.001 & 0.063 \\
\hline \multicolumn{11}{|c|}{ Feed intake (g/d) } \\
\hline Week 1- 3 & $46.04^{\mathrm{a}}$ & $43.27^{b}$ & $43.88^{b}$ & $45.58^{\mathrm{a}}$ & $45.18^{\mathrm{a}}$ & $42.43^{b}$ & 0.50 & 0.029 & 0.008 & 0.109 \\
\hline Week 4-6 & 143.79 & 145.81 & 141.33 & 144.79 & 144.65 & 141.50 & 1.33 & 0.403 & 0.534 & 0.456 \\
\hline Overall & 94.92 & 94.54 & 92.61 & 95.19 & 94.92 & 91.96 & 0.80 & 0.437 & 0.185 & 0.223 \\
\hline \multicolumn{11}{|c|}{ Feed conversion ratio } \\
\hline Week 3 & 1.61 & 1.60 & 1.63 & $1.58^{\mathrm{b}}$ & $1.59^{b}$ & $1.66^{\mathrm{a}}$ & 0.01 & 0.667 & 0.025 & 0.162 \\
\hline Week 6 & 1.85 & 1.83 & 1.86 & 1.86 & 1.84 & 1.84 & 0.01 & 0.601 & 0.891 & 0.650 \\
\hline Overall & 1.77 & 1.74 & 1.78 & 1.76 & 1.76 & 1.78 & 0.01 & 0.175 & 0.659 & 0.307 \\
\hline
\end{tabular}

${ }^{1}$ PO: $6 \%$ of palm oil in diet; SO: $6 \%$ of soybean oil in diet; LO: $6 \%$ of linseed oil in diet.

${ }^{2} \mathrm{Ca1}: 1 \% \mathrm{Ca}$ and $0.45 \% \mathrm{P}$; Ca2: 1.25\% Ca and 0. 56\% P; Ca3: $1.50 \% \mathrm{Ca}$ and $0.67 \% \mathrm{P}$.

${ }^{a, b}$ means within the same row for each parameter with different superscripts are significantly different $(P<0.05)$. 
Table 4 Effect of dietary oil sources, calcium and phosphorus levels on percentage (\%) of internal organs and abdominal fat in relative to live body weight of broiler chickens

\begin{tabular}{lcccc}
\hline Treatment group & Liver $\%$ & Gizzard $\%$ & Heart $\%$ & Abdominal fat $\%$ \\
\hline Oil source $^{1}$ & & & & \\
PO & 1.84 & 2.45 & 0.35 & $2.65^{\mathrm{a}}$ \\
SO & 1.74 & 2.39 & 0.34 & $2.08^{\mathrm{b}}$ \\
LO & 1.91 & 2.37 & 0.35 & $1.49^{\mathrm{c}}$ \\
Calcium level & & & & \\
Ca1 & & 2.47 & 0.34 & 2.11 \\
Ca2 & 1.81 & 2.30 & 0.34 & 2.00 \\
Ca3 & 1.76 & 2.44 & 0.35 & 2.11 \\
SEM & 1.93 & 0.04 & 0.01 & 0.06 \\
P-value & 0.03 & & & \\
Oil & & 0.718 & 0.433 & 0.001 \\
Ca & 0.069 & 0.248 & 0.608 & 0.130 \\
Oil $\times$ Ca & 0.066 & 0.684 & 0.549 & \\
\end{tabular}

${ }_{1}^{1} \mathrm{PO}: 6 \%$ of palm oil in diet; SO: $6 \%$ of soybean oil in diet; LO: $6 \%$ of linseed oil in diet.

${ }^{2} \mathrm{Ca1}$ : 1\% Ca and 0. 45\% P; Ca2: 1.25\% Ca and 0. 56\% P; Ca3: 1.50\% Ca and 0.67\% P.

${ }^{a-c}$ Means in the same column not sharing a common superscript are significantly different at $P<0.05$.

Table 5 Villi height and crypt depth in small intestine of broiler chickens at week 3 of supplementation with different sources of oil and levels of calcium

\begin{tabular}{|c|c|c|c|c|c|c|}
\hline \multirow{2}{*}{$\begin{array}{l}\text { Treatment } \\
\text { group }\end{array}$} & \multicolumn{3}{|c|}{ Villus height [ $\mu \mathrm{m}]$} & \multicolumn{3}{|c|}{ Crypt depth $[\mu \mathrm{m}]$} \\
\hline & Duodenum & Jejunum & Ileum & Duodenum & Jejunum & Ileum \\
\hline \multicolumn{7}{|l|}{ Oil source $^{1}$} \\
\hline PO & $1107^{\mathrm{a}}$ & $604^{\mathrm{a}}$ & 443 & $121^{\mathrm{b}}$ & $105^{\mathrm{b}}$ & 89 \\
\hline so & $1080^{a}$ & $612^{\mathrm{a}}$ & 460 & $127^{\mathrm{ab}}$ & $104^{\mathrm{b}}$ & 92 \\
\hline LO & $974^{\mathrm{b}}$ & $567^{\mathrm{b}}$ & 456 & $134^{\mathrm{a}}$ & $116^{\mathrm{a}}$ & 98 \\
\hline \multicolumn{7}{|c|}{ Calcium level $\left.\right|^{2}$} \\
\hline Ca1 & 1099 & 597 & 458 & 125 & 107 & 91 \\
\hline $\mathrm{Ca} 2$ & 1047 & 596 & 452 & 130 & 108 & 92 \\
\hline $\mathrm{Ca} 3$ & 1014 & 590 & 424 & 128 & 111 & 85 \\
\hline SEM & 16.46 & 6.53 & 3.79 & 1.75 & 1.81 & 2.18 \\
\hline \multicolumn{7}{|l|}{$P$-value } \\
\hline Oil & 0.009 & 0.010 & 0.184 & 0.006 & 0.018 & 0.228 \\
\hline $\mathrm{Ca}$ & 0.060 & 0.874 & 0.616 & 0.478 & 0.601 & 0.469 \\
\hline Oil $\times \mathrm{Ca}$ & 0.427 & 0.233 & 0.748 & 0.313 & 0.540 & 0.490 \\
\hline
\end{tabular}

${ }^{1} \mathrm{PO}$ : $6 \%$ of palm oil in diet; SO: $6 \%$ of soybean oil in diet; LO: $6 \%$ of linseed oil in diet.

${ }^{2} \mathrm{Ca1}$ : 1\% Ca and 0. 45\% P; Ca2: 1.25\% Ca and 0. 56\% P; Ca3: 1.50\% Ca and 0.67\% P.

a,b Means in the same column not sharing a common superscript are significantly different at $P<0.05$.

Intestinal villi play an important role as sites of nutrient absorption in the gastro intestinal tract. The absorption of nutrient takes place via intestinal villi with a height range from 0.5 to $1.5 \mu \mathrm{m}$ (Julendra et al., 2012). Nutrient absorption can be influenced by feed quality and digestibility (McDonald et al., 2002). Nutrient absorption is maximized if villi are not disrupted (Cheeke, 2005). Gut morphology characteristics of 
broiler chicken fed different dietary oil and Ca levels are shown in Tables 5 and 6, respectively. The duodenum and jejunum of birds fed SO and PO showed greater villus height $(P<0.05)$ compared with those fed LO in both the starter and finisher phases. However, the villus height of the ileum was unaffected by oil source. The crypt depth of the duodenum and jejunum was greater $(P<0.05)$ in birds fed LO than in other treatments in both the starter and finisher phases. The lower villi height in LO birds supported the findings of Xie et al. (2013), who reported that supplementing oil rich with n-3 polyunsaturated fatty acids (PUFA) in diet of squabs caused a lower bodyweight gain and affected villus morphology compared with lard, palm oil and soybean oil. Oils containing high proportions of readily oxidizable n-3 PUFA could lower the oxidative stability of gut, which could predispose cell or tissue to free radical attack. The high level of n-3 PUFA seemed to cause negative effects for epithelial cells (Calviello et al., 1999) and even induced mucosa apoptosis (Courtney et al., 2007) and reduced the villous height in rats (Perin et al., 1999).

Regardless of the oil source, the villus height and crypt depth in starter and finisher diets were not significantly different $(P<0.05)$ among Ca levels. The interactions among the various sources of oil and $\mathrm{Ca}$ levels were not statistically significant $(P>0.05)$.

Table 6 Villi height and crypt depth in small intestine of broiler chickens at week 6 of treatment supplemented with different sources of oil and levels of calcium

\begin{tabular}{|c|c|c|c|c|c|c|}
\hline \multirow{2}{*}{$\begin{array}{l}\text { Treatment } \\
\text { group }\end{array}$} & \multicolumn{3}{|c|}{ Villus height $[\mu \mathrm{m}]$} & \multicolumn{3}{|c|}{ Crypt depth $[\mu \mathrm{m}]$} \\
\hline & Duodenum & Jejunum & Ileum & Duodenum & Jejunum & Ileum \\
\hline \multicolumn{7}{|l|}{ Oil source ${ }^{1}$} \\
\hline $\mathrm{PO}$ & $1429^{a}$ & $999^{a}$ & 590 & $159^{\mathrm{ab}}$ & $160^{b}$ & 93 \\
\hline so & $1416^{a}$ & $985^{\mathrm{ab}}$ & 593 & $153^{b}$ & $157^{\mathrm{b}}$ & 88 \\
\hline LO & $1328^{b}$ & $946^{a}$ & 595 & $165^{a}$ & $172^{\mathrm{a}}$ & 91 \\
\hline \multicolumn{7}{|c|}{ Calcium level $^{2}$} \\
\hline Ca1 & 1411 & 968 & 595 & 160 & 163 & 92 \\
\hline $\mathrm{Ca} 2$ & 1399 & 997 & 594 & 157 & 159 & 87 \\
\hline Ca3 & 1363 & 965 & 588 & 161 & 166 & 93 \\
\hline SEM & 11.74 & 8.16 & 6.50 & 1.80 & 1.82 & 1.22 \\
\hline \multicolumn{7}{|l|}{$P$-value } \\
\hline Oil & 0.004 & 0.022 & 0.949 & 0.018 & 0.001 & 0.250 \\
\hline $\mathrm{Ca}$ & 0.166 & 0.211 & 0.891 & 0.596 & 0.190 & 0.180 \\
\hline Oil $\times \mathrm{Ca}$ & 0.115 & 0.573 & 0.065 & 0.305 & 0.080 & 0.220 \\
\hline
\end{tabular}

${ }^{1} \mathrm{PO}: 6 \%$ of palm oil in diet; SO: $6 \%$ of soybean oil in diet; LO: $6 \%$ of linseed oil in diet.

${ }^{2}$ Ca1: 1\% Ca and 0. 45\% P; Ca2: 1.25\% Ca and 0. 56\% P; Ca3: $1.50 \%$ Ca and 0.67\% P.

${ }^{a, b}$ means within the same column for each parameter with different superscripts are significantly different $(P<0.05)$.

Apparent nutrient digestibilities of the starter and grower diets in broiler chickens fed different sources of oil and $\mathrm{Ca}$ levels are shown in Tables 7 and 8. Apparent digestibility of organic matter, crude protein, ether extract and ash was not significantly different $(P>0.05)$ across dietary oil treatments. As observed in the current study, Jankowski et al. (2012) found that apparent digestibility of organic matter, ether extract, ash and crude protein was not significantly different in turkeys fed diets supplemented with linseed, rapeseed or soybean oils. In addition, Kavouridou et al. (2008) reported that dietary coconut oil, palm oil, olive oil, soybean oil and linseed oil did not influence nitrogen efficiency, but affected fat digestibility. The authors found that broiler chickens fed a diet containing PO had the lowest digestibility of fat.

Dietary oil source influenced $(P<0.05)$ digestibility of $\mathrm{Ca}$ and $\mathrm{P}$ in both the starter and grower periods. The present results showed that birds fed $\mathrm{PO}$ had lower digestibility of $\mathrm{Ca}$ in the finisher phase compared with those fed LO and SO. The present findings support those of Selle et al. (2009), who reported that free fatty acids, particularly saturated fatty acids, could bind with Ca-phytate complexes and form soluble or insoluble soap in the gut lumen (Selle et al., 2009) with the overall effect of reduced digestibility of both fat and $\mathrm{Ca}$. 
Table 7 Influence of dietary oil sources, calcium and phosphorus levels on apparent nutrient digestibility in broiler chickens at week 3

\begin{tabular}{|c|c|c|c|c|c|c|}
\hline \multirow{2}{*}{$\begin{array}{l}\text { Treatment } \\
\text { group }\end{array}$} & \multicolumn{6}{|c|}{ Digestibility coefficient (\%) } \\
\hline & $\begin{array}{c}\text { Organic } \\
\text { matter }\end{array}$ & Ether extract & $\begin{array}{l}\text { Crude } \\
\text { protein }\end{array}$ & Ash & Calcium & Phosphorus \\
\hline \multicolumn{7}{|l|}{ Oil source $^{1}$} \\
\hline PO & 76.37 & 68.86 & 76.72 & 31.09 & 54.40 & $71.77^{\mathrm{a}}$ \\
\hline so & 77.33 & 70.57 & 78.46 & 31.89 & 60.53 & $58.69^{b}$ \\
\hline LO & 75.54 & 70.91 & 75.69 & 32.48 & 53.27 & $45.97^{\mathrm{c}}$ \\
\hline \multicolumn{7}{|c|}{ Calcium level $^{2}$} \\
\hline Ca1 & $77.09^{\mathrm{a}}$ & $72.29^{b}$ & $78.33^{\mathrm{a}}$ & $29.66^{\mathrm{b}}$ & $49.74^{\mathrm{b}}$ & $56.30^{b}$ \\
\hline $\mathrm{Ca} 2$ & $77.96^{\mathrm{a}}$ & $74.33^{\mathrm{a}}$ & $79.72^{\mathrm{a}}$ & $33.76^{\mathrm{a}}$ & $67.74^{\mathrm{a}}$ & $69.88^{\mathrm{a}}$ \\
\hline $\mathrm{Ca} 3$ & $74.20^{b}$ & $63.72^{\mathrm{c}}$ & $72.82^{b}$ & $32.04^{\mathrm{a}}$ & $51.20^{\mathrm{b}}$ & $50.07^{c}$ \\
\hline \multicolumn{7}{|l|}{ Interaction } \\
\hline PO×Ca1 & 77.13 & 71.15 & 78.49 & 29.20 & 45.95 & $63.45^{\mathrm{bc}}$ \\
\hline $\mathrm{PO} \times \mathrm{Ca} 2$ & 77.93 & 73.53 & 78.99 & 32.98 & 72.41 & $89.19^{a}$ \\
\hline $\mathrm{PO} \times \mathrm{Ca} 3$ & 74.07 & 61.92 & 72.69 & 31.09 & 44.85 & $62.67^{\mathrm{bc}}$ \\
\hline SO $\times$ Ca1 & 78.01 & 72.96 & 79.37 & 29.74 & 52.45 & $66.01^{\mathrm{b}}$ \\
\hline $\mathrm{SO} \times \mathrm{Ca} 2$ & 78.96 & 74.44 & 81.89 & 33.91 & 72.37 & $56.45^{\mathrm{cd}}$ \\
\hline $\mathrm{SO} \times \mathrm{Ca} 3$ & 75.03 & 64.31 & 74.14 & 32.02 & 56.77 & $53.61^{d}$ \\
\hline LO×Ca1 & 76.13 & 72.76 & 77.13 & 30.03 & 49.37 & $39.44^{\mathrm{e}}$ \\
\hline LO×Ca2 & 77.00 & 75.02 & 78.30 & 34.40 & 58.44 & $64.00^{\mathrm{bc}}$ \\
\hline $\mathrm{LO} \times \mathrm{Ca} 3$ & 73.49 & 64.94 & 71.65 & 33.01 & 52.00 & $33.94^{\mathrm{e}}$ \\
\hline SEM & 0.41 & 0.97 & 0.74 & 0.49 & 2.19 & 2.69 \\
\hline \multicolumn{7}{|l|}{$P$-value } \\
\hline Oil & 0.082 & 0.093 & 0.081 & 0.448 & 0.179 & 0.001 \\
\hline $\mathrm{Ca}$ & 0.001 & 0.001 & 0.001 & 0.003 & 0.002 & 0.001 \\
\hline Oil $\times \mathrm{Ca}$ & 0.999 & 0.941 & 0.965 & 0.996 & 0.289 & 0.001 \\
\hline
\end{tabular}

${ }^{1} \mathrm{PO}: 6 \%$ of palm oil in diet; SO: $6 \%$ of soybean oil in diet; LO: $6 \%$ of linseed oil in diet.

${ }^{2} \mathrm{Ca1}$ : 1\% Ca and 0. 45\% P; Ca2: 1.25\% Ca and 0. 56\% P; Ca3: 1.50\% Ca and 0.67\% P.

${ }^{\mathrm{a}-\mathrm{e}}$ Means in the same column not sharing a common superscript are significantly different at $P<0.05$.

The apparent digestibility of organic matter, crude protein, ether extract, ash, $\mathrm{Ca}$ and $\mathrm{P}$ was significantly different $(P<0.05)$ between Ca levels in starter and finisher diets. Birds fed $1.25 \%$ Ca had higher digestibility of organic matter, crude protein, ether extract, ash and $\mathrm{P}$ compared with those fed $1.5 \% \mathrm{Ca}$. Birds fed $1.25 \% \mathrm{Ca}$ had higher digestibility of ether extract, ash, $\mathrm{Ca}$ and $\mathrm{P}$ compared with those fed $1 \%$ of Ca. Underwood \& Suttle (2001) found that low dietary Ca concentrations resulted in poor bone development and growth, and deficiency of $\mathrm{Ca}$ in layer diets resulted in soft-shelled eggs. High dietary Ca concentrations adversely influenced apparent nutrient digestibility (Underwood \& Suttle, 2001). The current findings are in general agreement with previous reports (Rao et al., 2006; Tancharoenrat \& Ravindran, 2014; Wilkinson et al., 2014). One possible explanation for the negative effects of high Ca may be the increase in $\mathrm{pH}$ in the upper gastrointestinal tract. Increasing the dietary Ca concentration through the use of limestone could be expected to increase gastrointestinal pH owing to its extremely high acid binding capacity (Selle et al., 2009). Therefore, additional $\mathrm{Ca}$ as limestone could increase insoluble Ca-phytate complex formation by increasing gut $\mathrm{pH}$ and $\mathrm{Ca}$ : phytate molar ratios.

The interaction among different sources of oil and Ca levels was significant different $(P<0.05)$ for mineral digestibility. 
Table 8 Influence of dietary oil sources, calcium and phosphorus levels on apparent nutrient digestibility in broiler chickens at week 6

\begin{tabular}{|c|c|c|c|c|c|c|}
\hline \multirow{2}{*}{$\begin{array}{l}\text { Treatment } \\
\text { group }\end{array}$} & \multicolumn{6}{|c|}{ Digestibility coefficient (\%) } \\
\hline & $\begin{array}{c}\text { Organic } \\
\text { matter }\end{array}$ & Ether extract & $\begin{array}{l}\text { Crude } \\
\text { protein }\end{array}$ & Ash & Calcium & Phosphorus \\
\hline \multicolumn{7}{|l|}{ Oil source $^{1}$} \\
\hline $\mathrm{PO}$ & 79.34 & 73.52 & 79.66 & 34.95 & $54.02^{c}$ & $46.28^{a}$ \\
\hline So & 80.33 & 74.61 & 80.81 & 35.77 & $67.57^{\mathrm{a}}$ & $36.18^{b}$ \\
\hline LO & 78.50 & 75.10 & 78.96 & 36.43 & $62.45^{\mathrm{b}}$ & $37.18^{\mathrm{b}}$ \\
\hline \multicolumn{7}{|c|}{ Calcium level $^{2}$} \\
\hline Ca1 & $79.96^{\mathrm{a}}$ & $76.97^{\mathrm{a}}$ & $82.00^{\mathrm{a}}$ & $33.67^{c}$ & $56.35^{c}$ & $37.05^{\mathrm{b}}$ \\
\hline Ca2 & $81.18^{\mathrm{a}}$ & $78.08^{\mathrm{a}}$ & $82.22^{\mathrm{a}}$ & $37.84^{\mathrm{a}}$ & $60.35^{\mathrm{b}}$ & $50.53^{\mathrm{a}}$ \\
\hline $\mathrm{Ca} 3$ & $77.04^{b}$ & $68.18^{\mathrm{b}}$ & $75.22^{b}$ & $35.65^{b}$ & $67.34^{\mathrm{a}}$ & $32.12^{\mathrm{c}}$ \\
\hline \multicolumn{7}{|l|}{ Interaction } \\
\hline PO×Ca1 & 79.98 & 75.91 & 81.51 & 33.00 & $47.87^{d}$ & $49.57^{\mathrm{ab}}$ \\
\hline $\mathrm{PO} \times \mathrm{Ca} 2$ & 81.13 & 77.49 & 82.36 & 37.12 & $57.90^{c}$ & $56.63^{\mathrm{a}}$ \\
\hline $\mathrm{PO} \times \mathrm{Ca} 3$ & 76.91 & 67.16 & 75.12 & 34.74 & $56.29^{c}$ & $33.00^{\mathrm{de}}$ \\
\hline $\mathrm{SO} \times \mathrm{Ca} 1$ & 80.86 & 77.41 & 83.52 & 34.12 & $63.51^{\mathrm{bc}}$ & $26.24^{\mathrm{e}}$ \\
\hline $\mathrm{SO} \times \mathrm{Ca} 2$ & 82.03 & 78.02 & 82.97 & 37.53 & $61.90^{\mathrm{cb}}$ & $52.52^{\mathrm{a}}$ \\
\hline $\mathrm{SO} \times \mathrm{Ca} 3$ & 78.11 & 68.39 & 75.96 & 35.68 & $77.30^{\mathrm{a}}$ & $29.79^{\mathrm{e}}$ \\
\hline LO×Ca1 & 79.03 & 77.60 & 80.96 & 33.91 & $57.68^{c}$ & $35.35^{\mathrm{cd}}$ \\
\hline $\mathrm{LO} \times \mathrm{Ca} 2$ & 80.38 & 78.73 & 81.34 & 38.88 & $61.25^{\mathrm{bc}}$ & $42.81^{\mathrm{bc}}$ \\
\hline $\mathrm{LO} \times \mathrm{Ca} 3$ & 76.09 & 68.99 & 74.57 & 36.52 & $68.42^{\mathrm{b}}$ & $33.57^{\mathrm{de}}$ \\
\hline SEM & 0.41 & 0.91 & 0.71 & 0.44 & 1.47 & 1.89 \\
\hline \multicolumn{7}{|l|}{$P$-value } \\
\hline Oil & 0.053 & 0.069 & 0.082 & 0.263 & 0.001 & 0.002 \\
\hline $\mathrm{Ca}$ & 0.001 & 0.001 & 0.001 & 0.001 & 0.001 & 0.001 \\
\hline Oil $\times \mathrm{Ca}$ & 0.999 & 0.977 & 0.943 & 0.964 & 0.017 & 0.008 \\
\hline
\end{tabular}

${ }^{1} \mathrm{PO}: 6 \%$ of palm oil in diet; SO: $6 \%$ of soybean oil in diet; LO: $6 \%$ of linseed oil in diet.

${ }^{2} \mathrm{Ca} 1 \mathrm{1}$ : $\% \mathrm{Ca}$ and 0. 45\% P; Ca2: 1.25\% Ca and 0. 56\% P; Ca3: 1.50\% Ca and 0.67\% P.

a-e Means in the same column not sharing a common superscript are significantly different at $P<0.05$.

\section{Conclusion}

The present study demonstrated that high Ca concentrations in broiler diets, regardless of oil source, resulted in negative effects on the performance of the birds. Broilers fed diets containing $1.25 \%$ Ca showed higher weight gain and nutrient digestibility compared with 1.5\%, and higher ash and mineral digestibility compared with $1 \% \mathrm{Ca}$. In addition, dietary oils differ in their effects on growth performance, gut morphology and apparent nutrient digestability of minerals in broiler chickens. The interaction between various sources of oil and $\mathrm{Ca}$ levels was significant $(P<0.05)$ for mineral digestibility, but not significant $(P>0.05)$ for growth performance, gut morphology and relative weight of internal organs.

\section{Acknowledgements}

This project was supported by Long-Term Research Grant Scheme (LRGS) from Ministry of Education Malaysia.

\section{Authors' contributions}

TCL and HLF contributed to the idea, design and execution of the study. NRA, TCL and AQS assisted in all broiler chicken procedures for the experiment. NRA and HA performed the digestibility analysis, whereas HLF and NRA contributed for the measurement of intestinal morphology. TCL and NRA were responsible for the statistical analysis. All authors contributed equally to the write-up of the final manuscript. 


\section{Conflict of interest declaration}

The authors declare that there is no conflict of interests regarding the publication of this manuscript.

\section{Reference}

Abdulla, N., Loh, T., Akit, H., Sazili, A., Foo, H., Mohamad, R., Rahim, R.A., Ebrahimi, M. \& Sabow, A., 2015. Fatty acid profile, cholesterol and oxidative status in broiler chicken breast muscle fed different dietary oil sources and calcium levels. S. Afr. J. Anim. Sci. 45, 153-163.

AOAC, 1995. Official Method of Analysis, 16th ed., Association of Official Analytical Chemist, AOAC International, Arlington, USA.

Atteh, J. \& Leeson, S., 1983. Effects of dietary fatty acids and calcium levels on performance and mineral metabolism of broiler chickens. Poult. Sci. 62, 2412-2419.

Baião, N.C. \& Lara, L., 2005. Oil and fat in broiler nutrition. Rev. Bras. Cienc. Avi. 7, 129-141.

Calviello, G., Palozza, P., Maggiano, N., Piccioni, E., Franceschelli, P., Frattucci, A., Di Nicuolo, F. \& Bartoh, G.M., 1999. Cell proliferation 'differentiation' and apoptosis are modified by $n-3$ polyunsaturated fatty acids in normal colonic mucosa. Lipids 34, 599-604.

Cheeke, P.R., 2005. Applied Animal Nutrition, Feeds and Feeding, 3rd ed., Pearson Prentice Hall, New Jersey, USA.

Choe, D., Loh, T., Foo, H., Hair-Bejo, M. \& Awis, Q., 2012. Egg production, faecal pH and microbial population, small intestine morphology, and plasma and yolk cholesterol in laying hens given liquid metabolites produced by Lactobacillus plantarum strains. Br. Poult. Sci. 53, 106-115.

Chwen, L.T., Foo, H.L., Thanh, N.T. \& Choe, D., 2013. Growth performance, plasma fatty acids, villous height and crypt depth of preweaning piglets fed with medium chain triacylglycerol. Asian. Austral. J. Anim. 26, 700-704.

Courtney, E., Matthews, S., Finlayson, C., Di Pierro, D., Belluzzi, A., Roda, E., Kang, J. \& Leicester, R., 2007. Eicosapentaenoic acid (EPA) reduces crypt cell proliferation and increases apoptosis in normal colonic mucosa in subjects with a history of colorectal adenomas. Int. J. Clorectal Dis. 22, 765-776.

Crespo, N. \& Esteve-Garcia, E., 2001. Dietary fatty acid profile modifies abdominal fat deposition in broiler chickens. Poult. Sci. 80, 71-78.

Crespo, N. \& Esteve-Garcia, E., 2002a. Dietary linseed oil produces lower abdominal fat deposition but higher de novo fatty acid synthesis in broiler chickens. Poult. Sci. 81, 1555-1562.

Crespo, N. \& Esteve-Garcia, E., 2002b. Dietary polyunsaturated fatty acids decrease fat deposition in separable fat depots but not in the remainder carcass. Poult. Sci. 81, 512-518.

Department of Standards Malaysia, 2009. Malaysia Standards 1500: 2009 (1st revision) Halal food- production preparation handling and storage. General guideline. Department of Standards Malaysia- sia, Cyberjaya, Selangor.

De Witt, F., Els, S., Van der Merwe, H., Hugo, A. \& Fair, M., 2009. Effect of dietary lipid sources on production performance of broilers. S. Afr. J. Anim. Sci. 39, 45-48.

Fébel, H., Mezes, M., Palfy, T., Herman, A., Gundel, J., Lugasi, A., Balogh, K., Kocsis, I. \& Blazovics, A., 2008. Effect of dietary fatty acid pattern on growth, body fat composition and antioxidant parameters in broilers. J. Anim. Physiol. An. N. 92, 369-376.

Jankowski, J., Zduńczyk, P., Mikulski, D., Juśkiewicz, J., Mikulska, M. \& Zduńczyk, Z., 2012. Effects of dietary soyabean, rapeseed and linseed oils on performance, slaughter yield and fatty acid profile of breast meat in turkeys. J. Anim. Feed Sci. 21, 143-156.

Julendra, H., Damayanti, E., Lusty Istiqomah, S.N. \& Karimy, M.F., 2012. The effectiveness of earthworm meal supplementation as antibiotic growth promoter replacer with different processing method. The 1st Poult. Int. Sem. 146-157.

Kavouridou, K., Barroeta, A., Villaverde, C., Manzanilla, E. \& Baucells, M., 2008. Fatty acid, protein and energy gain of broilers fed different dietary vegetable oils. Span. J. Agric. Res. 6, 210-218.

Leeson, S. \& Atteh, J., 1995. Utilization of fats and fatty acids by turkey poults. Poult. Sci. 74, 2003-2010.

Leeson, S. \& Summers, J., 2005. Commercial Poultry Production. University Books, Guelph, Ontario, Canada. ISBN, 969560052: pp. 63-64.

Maroufyan, E., Kasim, A., Bejo, M.H., Loh, T.C., Soleimani, A. \& Ebrahimi, M., 2013. Functional alteration of breast muscle fatty acid profile by manipulation of dietary n-6 : n-3 ratios in broiler chickens. Afr. J. Biotechnol. 10, 16101-16106.

McDonald, P., Edwards, R.A., Greenhalgh, J.F.D. \& Morgan, C.A., 2002. Animal Nutrition. Pearson Education Limited, Essex, UK.

NRC, 1994. Nutrient requirements of poultry. National Research Council, National Academy Press Washington, D.C., USA.

Perin, N., Jarocka-Cyrta, E., Keelan, M., Clandinin, T. \& Thomson, A., 1999. Dietary lipid composition modifies intestinal morphology and nutrient transport in young rats. J. Pediatr. Gastr. Nutr. 28, 46-53

Peters, J.C. \& Mahan, D.C., 2008. Effects of dietary organic and inorganic trace mineral levels on sow productive performance and daily mineral intakes over six parities. J. Anim. Sci. 86, 2247-2260.

Rao, S.R., Raju, M., Reddy, M. \& Pavani, P., 2006. Interaction between dietary calcium and non-phytate phosphorus levels on growth, bone mineralization and mineral excretion in commercial broilers. Anim. Feed Sci. Technol. 131, $135-150$.

Ruttanavut, J. \& Yamauchi, K., 2010. Growth performance and histological alterations of intestinal villi in broilers fed dietary mixed minerals. Asian J. Anim. Sci. 4, 96-106. 
Santos, F.S., Farnell, M., Tellez, G., Balog, J., Anthony, N., Torres-Rodriguez, A., Higgins, S., Hargis, B. \& Donoghue, A., 2005. Effect of prebiotic on gut development and ascites incidence of broilers reared in a hypoxic environment. Poult. Sci. 84, 1092-1100.

SAS, 2007. User's Guide. 9.2 ed., In: SAS institute, Inc., Cary, N.C., USA.

Selle, P.H., Cowieson, A.J. \& Ravindran, V., 2009. Consequences of calcium interactions with phytate and phytase for poultry and pigs. Livest. Sci. 124, 126-141.

Shafey, T., 1999. Effects of high dietary calcium and fat levels on the performance, intestinal $\mathrm{pH}$, body composition and size and weight of organs in growing chickens. Asian. Austral. J. Anim. 12, 49-55.

Short, F., Gorton, P., Wiseman, J. \& Boorman, K., 1996. Determination of titanium dioxide added as an inert marker in chicken digestibility studies. Anim. Feed Sci. Technol. 59, 215-221.

Smith, M., Soisuvan, K. \& Miller, L., 2003. Evaluation of dietary calcium level and fat source on growth performance and mineral utilization of heat-distressed broilers. Poult. Sci. 2, 32-37.

Sola-Ojo, F.E., Adeyemi, K.D., Toye, A.A., Bolu, S.A., Fayeye, T.R., Annongu, A.A. \& Karim, R.O., 2013. Performance, carcass profile and oxidative stability of broiler chickens fed processed baobab seed meal. Bull. Env. Pharmacol. Life. Sci. 11, 94-99.

Tancharoenrat, P. \& Ravindran, V., 2014. Influence of tallow and calcium concentrations on the performance and energy and nutrient utilization in broiler starters. Poult. Sci. 93, 1453-1462.

Underwood, E.J. \& Suttle, N.F., 2001. The Mineral Nutrition of Livestock. 3rd ed. CAB International, Wallingford, UK.

Villaverde, C., Baucells, M.D., Cortinas, L., Hervera, M. \& Barroeta, A.C., 2005. Chemical composition and energy content of chickens in response to different levels of dietary polyunsaturated fatty acids. Arch. Anim. Nutr. 59, 281-292.

Wilkinson, S., Selle, P., Bedford, M. \& Cowieson, A.J., 2014. Separate feeding of calcium improves performance and ileal nutrient digestibility in broiler chicks. Anim. Prod. Sci. 54, 172-178.

Xie, P., Wang, Y., Wang, C., Yuan, C. \& Zou, X., 2013. Effect of different fat sources in parental diets on growth performance, villus morphology, digestive enzymes and colorectal microbiota in pigeon squabs. Arch. Anim. Nutr. 67, 147-160.

Zhong, X., Gao, S., Wang, J., Dong, L., Huang, J., Zhang, L. \& Wang, T., 2014. Effects of linseed oil and palm oil on growth performance, tibia fatty acid and biomarkers of bone metabolism in broilers. Br. Poult. Sci. 55, 335-342.

Zulkifli, I., Htin, N.N., Alimon, A., Loh, T. \& Hair-Bejo, M., 2007. Dietary selection of fat by heat-stressed broiler chickens. Asian Austral. J. Anim. 20, 245- 251. 